\title{
80 才以上高齢者肺癌切除16例の検討
}

\author{
西山 祥行，黒木 基夫，西村 光世，兼安 秀人， \\ 高橋 健郎，松山 智治
}

\begin{abstract}
要 旨
過去 7 年間に当院において切除された 80 オ以上の原発性肺癌16例（肺癌切除例の $4 \%$ ）について検討 した.

1） 16 例中男性が 13 例と多く，術後病期では I 期 7 例， II 期 7 例， $\mathrm{N}$ 期 2 例で，組織型は腺癌 7 例，扁 平上皮癌 7 例, 大細胞癌 1 例, 小細胞癌 1 例であった。発見動機は自覚症状 9 例, 他疾患発見 6 例, 老 人検診 1 例であった.

2) 手術術式では前期の 8 例は単純肺葉切除のみであるが, 最近の 8 例では緹隔リンパ節郭清を含めた 肺葉切除がおてなわれており, 全摘例あるいは区域・部分切除例はない.

3）予後では 16 例全体の 5 年生存率は $26.3 \%$ で， 5 例が 8 年〜 3 年の生存例である. 術死が 1 例, 院内 死が 2 例にみられた.

以上の検討により80才以上の高齢者肺癌に対してあ, 術前心肺機能および病期を十分検討した上で, 外科治療を考慮すべきと考える.
\end{abstract}

索引用語：80才以上高齢者肺癌，術後合併症，外科治療. Elder patient over 80 years-old, Post operative complication, Surgery.

\section{はじめに}

近年我が国に抢いても高齢者肺癌は, 平均寿 命の伸びとともに肺癌症例中に占める割合が増 加しており, 術前術後管理の進歩と相まって高 歯者肺癌切除例も増加している. 高歯者では, 生理学的な臟器の老化とともに既往の疾患によ る諸臟器の機能低下がみられるため, 高齢者肺 癌の外科治療に際しては, 暦年齢とともに生理 学的年齢も十分に考慮して手術適応を決定する 必要がある。

従来対象となった高齢者の大部分は70才代で あり，80才以上の手術例の報告はわずかであっ た. 本稿では当院において経験した80才以上の 肺癌切除例についてその治療成績と術前術後管

\section{国立療養所松戸病院外科}

干271 松戸市高塚新田123-1

原稿受付 1988年 9 月 21 日

原稿採択 1988年10月24日
理の問題点および対策について検討した.

\section{対象}

昭和 54 年 1 月より昭和 60 年 12 月までの 7 年間 に当院において切除された 80 才以上の原発性肺 癌16例を対象とした. これは同時期の当院にお ける全肺癌切除例 403 例の $4 \%$ に相当する.

また当院において肺癌治療を開始した昭和 47 年以後に肺癌切除術を行なった 70 才以上の手術

表 1 年代別肺癌切除例中の高齢者の割合

\begin{tabular}{|c|c|c|c|}
\hline & $\stackrel{\text { 昭和 } 47}{\sim \text { 昭和 } 53}$ & $\begin{array}{l}\text { 昭和54 } \\
\sim \text { 昭和 } 57\end{array}$ & $\begin{array}{l}\text { 昭和 } 58 \\
\sim \text { 昭和 } 60\end{array}$ \\
\hline $\begin{array}{l}\text { 全切除例 } \\
\text { 年 齢 }\end{array}$ & 123例 & 211例 & 192例 \\
\hline 70才〜79才 & $\begin{array}{c}27 \\
(22.0 \%)\end{array}$ & $\begin{array}{c}63 \\
(29.9 \%)\end{array}$ & $\begin{array}{c}56 \\
(29.2 \%)\end{array}$ \\
\hline 80才〜 & 0 & $\begin{array}{c}8 \\
(3.8 \%)\end{array}$ & $(4.2 \%)$ \\
\hline
\end{tabular}




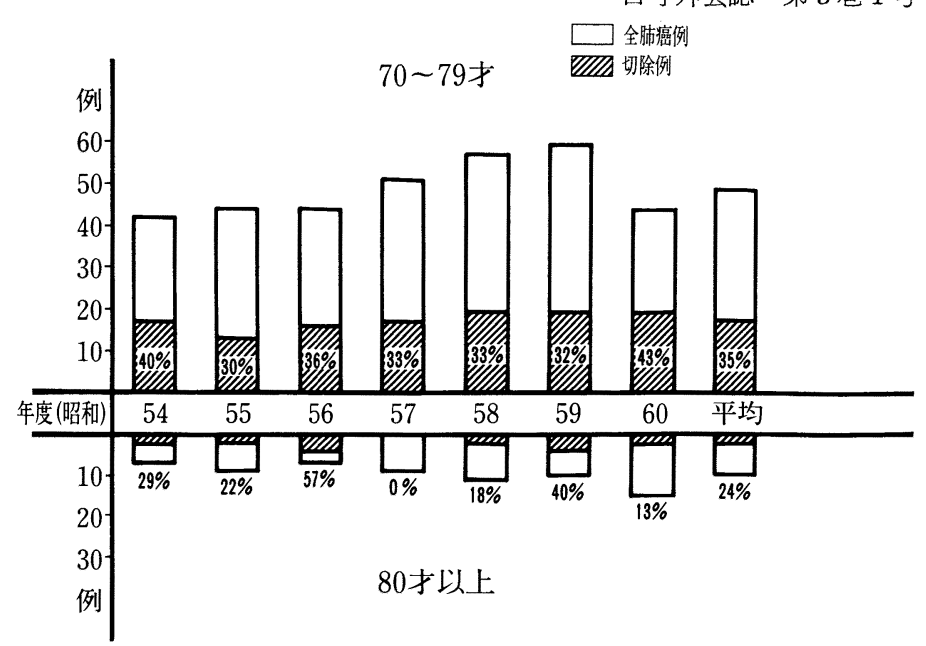

図 1 年度別の高齢者肺癌切除率

例を 3 期間に分けてみると，表 1 に示すごとく

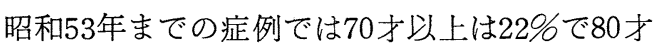
代はなく，今回検討した昭和54年以降では70才 代で $29 \% ， 80$ オでも 3 ～4\% と高龄者切除例が 増加している. しかし, 昭和54年以降では前半 と後半では，70才代，80才代ともにほとんど差 はみられなかった。

また，昭和54年以降毎年の70才以上の全肺癌 症例および切除例を示したものが図 1 であるが, 70才代（上段）では30\%～43\%（平均35\%）の 切除率であり，下段の80才代においても $0 \%$ $57 \%$ どらつきはあるが平均 $24 \%$ の切除率であ った。 このうち80才代での内科的治療となった 52 例で，手術適応がありながら本人あるいは家 族の同意が得られず手術できなかった症例は 4 例（臨床病期では Stage 1 が 3 例, Stage III が 1 例）のみであった. 残りの48例は全てIII， IV 期の進行例で根治の可能性が少なく, 手術の適 応とならなかった症例である。

結 果: 表 2 は 80 才以上肺癌切除例16例を手術 年代順に表にまとめたあのであるが，年齢は80 才から84才で, 性別では男性13例, 女性 3 例. 術後病期では I 期 7 例, III 期 7 例, IV 期 2 例で, 組織型は腺癌 7 例, 扁平上皮癌 7 例, 大細胞癌 1 例，小細胞癌 1 例であった．乙れを同時期の 全肺癌切除例と比べると高齢者例で男性がやや 多い以外は，ほぼ同様であり特に80才以上の高 齢者による特徴はみられなかった，発見動機は
咳, 痰, 発熱等の自覚症状で近医を受㡣し, 発 見されたものが 9 例之最む多く, 他疾患発見 6 例, 老人検診は 1 例のみであった. Performance Status はいずれあ0〜1であった.

次に16例の術前の併発症（表 3 ）をみると高 血圧 5 例, 糖氺病 3 例, それに膀胱癌, 喘息, 貧血, 白内障, 脳梗塞の各 1 例がみられ, 心電 図上 7 例に異常（虚血性変化 3 例, 期外収縮 3 例, 右脚ブロック 1 例）を認めた。

また, 術前の肺機能検査では図 2 のごとく数 值上ではきわめて低肺機能患者が数例見られる が，乙れらは検查の目的をよく理解できず，う まく検査ができなかったり，入れ歯の影響でマ ウスピースが合わなかったりした症例と考えら れ，得られたデータが必ずしす正確な数值を表 していると思われない. 全体として閉塞性障害 の傾向はみられるが，術前の肺機能と術後の呼 吸器合併症の間に明らかな関連は見られなかっ た.

次に手術術式では（表 4） 2 葉切除 1 例, 肺 葉切除15例で, 肺摘除例あるいは区域・部分切 除例はない.このうち隣接肺葉や胸膜, 横隔膜 への浸潤あるいは癒着のため合併切除を要した あのや気管支楔状切除や肺動脈部分切除例が10 例みられた。

リンパ節郭清については昭和 54 年から昭和 57 年までは, 高齢者であり過度の侵襲を避けたい という考えから縦隔の郭清を施行しておらず, 
表2 80 才以上高齢者肺癌切除例

\begin{tabular}{|c|c|c|c|c|c|c|c|c|c|}
\hline 症例 & 年齢 & 性 & 組織型 & 発見動機 & 病期 & $p-T N M$ & 術 式 & $\begin{array}{l}\text { リンパ節 } \\
\text { 郭清範囲 }\end{array}$ & 予 \\
\hline 1 & 80 & M & $\mathrm{p} / \mathrm{d} \mathrm{sq}$. & 自覚症状 & I & $\mathrm{T}_{2} \mathrm{~N}_{0} \mathrm{M}_{0}$ & 右上葉切除 & $\mathrm{R}_{0}$ & $\begin{array}{l}3 \text { 个月 } \\
\text { 死亡(肺炎) }\end{array}$ \\
\hline 2 & 83 & $\mathrm{~F}$ & $\mathrm{p} / \mathrm{d} \mathrm{sq}$. & 自覚症状 & III A & $\mathrm{T}_{3} \mathrm{~N}_{0} \mathrm{M}_{0}$ & $\begin{array}{l}\text { 右下葉切除 } \\
\text { 壁側胸膜 }\end{array}$ & $\mathrm{R}_{0}$ & $\begin{array}{l}8 \text { 年 } 4 \text { ケ月 } \\
\text { 生 存 }\end{array}$ \\
\hline 3 & 81 & M & $\mathrm{m} / \mathrm{d} \mathrm{sq}$ & 自覚症状 & I & $\mathrm{T}_{2} \mathrm{~N}_{0} \mathrm{M}_{0}$ & $\begin{array}{l}\text { 左上葉切除 } \\
\text { PA 部分 }\end{array}$ & $\mathrm{R}_{1}$ & $\begin{array}{l}8 \text { 年 } 1 \text { ケ月 } \\
\text { 生 存 }\end{array}$ \\
\hline 4 & 81 & M & $\mathrm{p} / \mathrm{d}$ sq. & $\begin{array}{l}\text { 他疾患 } \\
\text { 治療中 }\end{array}$ & I & $\mathrm{T}_{2} \mathrm{~N}_{0} \mathrm{M}_{0}$ & 左下葉切除 & $\mathrm{R}_{0}$ & $\begin{array}{l}\text { 術 死 } \\
\text { 肺 炎 }\end{array}$ \\
\hline 5 & 83 & $\mathrm{~F}$ & $\mathrm{~m} / \mathrm{d} \mathrm{sq}$. & $\begin{array}{l}\text { 他疾患 } \\
\text { 治療中 }\end{array}$ & I & $\mathrm{T}_{2} \mathrm{~N}_{0} \mathrm{M}_{0}$ & $\begin{array}{l}\text { 右上·葉切除 } \\
\text { 中到 }\end{array}$ & $\mathrm{R}_{1}$ & 癌 死 \\
\hline 6 & 82 & M & $\mathrm{m} / \mathrm{d}$ adeno & 自覚症状 & III A & $\mathrm{T}_{3} \mathrm{~N}_{0} \mathrm{M}_{0}$ & $\begin{array}{l}\text { 右上葉切除 } \\
\mathrm{S}^{6}, \mathrm{~S}^{8} \text { 部分 }\end{array}$ & $\mathrm{R}_{0}$ & $\begin{array}{l}5 \text { 年10ケ月 } \\
\text { 死亡 }\end{array}$ \\
\hline 7 & 81 & M & $\mathrm{m} / \mathrm{d}$ adeno & $\begin{array}{l}\text { 他疾患 } \\
\text { 治療中 }\end{array}$ & III B & $\mathrm{T}_{4} \mathrm{~N}_{0} \mathrm{M}_{0}$ & $\begin{array}{l}\text { 右中葉切除 } \\
S^{3} \text { 部分 }\end{array}$ & $\mathrm{R}_{0}$ & $\begin{array}{l}5 \text { ケ月 } \\
\text { 癌 死 }\end{array}$ \\
\hline 8 & 80 & $\mathrm{~F}$ & $\begin{array}{l}\text { adeno } \\
\left(\begin{array}{c}\text { bronchiolo- } \\
\text { alveolar }\end{array}\right)\end{array}$ & 自覚症状 & IV & $\mathrm{T}_{2} \mathrm{~N}_{0} \mathrm{M}_{1}$ & 右下葉切除 & $\mathrm{R}_{0}$ & $\begin{array}{l}4 \text { 年 } 11 \text { ケ月 } \\
\text { 癌 死 }\end{array}$ \\
\hline 9 & 84 & M & $\mathrm{m} / \mathrm{d} \mathrm{sq}$ & $\begin{array}{l}\text { 他痴患 } \\
\text { 治療中 }\end{array}$ & III A & $\mathrm{T}_{2} \mathrm{~N}_{2} \mathrm{M}_{0}$ & $\begin{array}{l}\text { 右下葉切除 } \\
\text { 横隔膜部分 }\end{array}$ & $\mathrm{R}_{2}$ & $\begin{array}{l}\text { 11ケ月 } \\
\text { 癌 死 }\end{array}$ \\
\hline 10 & 80 & M & small & 自覚症状 & III A & $\mathrm{T}_{3} \mathrm{~N}_{1} \mathrm{M}_{0}$ & $\begin{array}{l}\text { 右上葉切除 } \\
\text { 気管支楔状 }\end{array}$ & $\mathrm{R}_{1}$ & $\begin{array}{c}1 \text { 年 } 3 \text { ケ月 } \\
\text { 死 }\end{array}$ \\
\hline 11 & 81 & M & $\mathrm{w} / \mathrm{d}$ adeno & 検 診 & I & $\mathrm{T}_{2} \mathrm{~N} \circ \mathrm{M}_{0}$ & 右中葉切除 & $\mathrm{R}_{2}$ & $\begin{array}{l}1 \text { 年 } 3 \text { ケ月 } \\
\text { 死 亡 }\end{array}$ \\
\hline 12 & 80 & M & $\mathrm{p} / \mathrm{d} \mathrm{sq}$. & $\begin{array}{l}\text { 他疾患 } \\
\text { 治療中 }\end{array}$ & III A & $\mathrm{T}_{3} \mathrm{~N}_{0} \mathrm{M}_{0}$ & $\begin{array}{l}\text { 右下葉切除 } \\
\text { 壁側胸膜 }\end{array}$ & $\mathrm{R}_{2}$ & 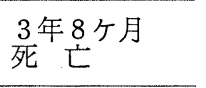 \\
\hline 13 & 81 & M & $\mathrm{m} / \mathrm{d}$ adeno & 自覚症状 & IV A & $\mathrm{T}_{2} \mathrm{~N}_{0} \mathrm{M}_{1}$ & $\begin{array}{l}\text { 右上葉切除 } \\
\text { 譬側胸膜 } \\
\mathrm{S}^{6}, \mathrm{~S}^{4} \text { 部分 }\end{array}$ & $\mathrm{R}_{2}$ & $\begin{array}{l}5 \text { ケ月 } \\
\text { 死亡(肺炎) }\end{array}$ \\
\hline 14 & 81 & M & $\mathrm{m} / \mathrm{d}$ adeno & 自覚症状 & III $\mathrm{A}$ & $\mathrm{T}_{2} \mathrm{~N}_{2} \mathrm{M}_{0}$ & 左上葉切除 & $\mathrm{R}_{2}$ & $\begin{array}{l}4 \text { ケ月 } \\
\text { 癌 死 }\end{array}$ \\
\hline 15 & 82 & M & large & $\begin{array}{l}\text { 他疾患 } \\
\text { 治療中 }\end{array}$ & I & $\mathrm{T}_{2} \mathrm{~N}_{0} \mathrm{M}_{0}$ & 右下葉切除 & $\mathrm{R}_{2}$ & $\begin{array}{l}2 \text { 年10ケ月 } \\
\text { 生 存 }\end{array}$ \\
\hline 16 & 80 & M & $\mathrm{m} / \mathrm{d} \mathrm{sq}$ & 自覚症状 & I & $\mathrm{T}_{2} \mathrm{~N}_{0} \mathrm{M}_{0}$ & $\begin{array}{l}\text { 右中葉切除 } \\
\mathrm{S}^{3}, \mathrm{~S}^{6} \text { 部分 }\end{array}$ & $\mathrm{R}_{2}$ & $\begin{array}{l}2 \text { 年 } 9 \text { 个月 } \\
\text { 生存(局所再発) }\end{array}$ \\
\hline
\end{tabular}

sq. : : squamous cell carcinoma

adeno: adenocarcinoma

large : large cell carcinoma

small : small cell carcinoma $\mathrm{w} / \mathrm{d}$ : well differentiated

$\mathrm{m} / \mathrm{d}$ : moderately differentiated

$\mathrm{p} / \mathrm{d}$ : poorly differentiated
8 例は不完全郭清 $\left(\mathrm{R}_{0} \sim \mathrm{R}_{1}\right)$ 例であるが，昭和 58年以降は80才以上でもリンパ節郭清 $\left(\mathrm{R}_{2}\right)$ を 含めた肺葉切除を原則としている。すなわち根 治度別では相対的非治癒切除が 7 例と最も多 <, 絶対的治癒切除 3 例, 相対的治癒切除 3 例, 絶対的非治癒切除 3 例であった。
術後の合併症では痰喀出困難例が最も多く, 8 例に頻回の気管支ファイバースコープによる 吸痰を要したが，最近では術後の硬膜外麻酔に よる疼痛除去により, 早期離床や痰の喀出が容 易となり気管支ファイバースコープによる吸痰 の回数屯減少している. また 5 例に一過性の不 
表 3 術前併発症

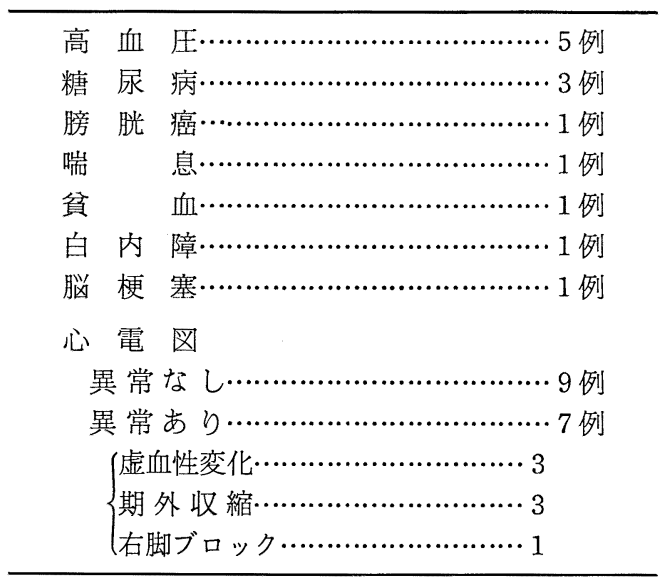

整脈を 2 例に消化管潰瘍を，また肺炎，無気肺 を各 1 例に認めたが，いずれも治療により改善 した.また，乙れらの16例では術後の精神障害 はみられなかった。

予後では図 3 に示したごとく全例の 5 年生存 率は26.3\%であり，病期別でみると Stage I

（術死 1 例を除く） 50\%, Stage III 28.6\%と， その年齢を考慮すれば良好と思われる，個々の 例では表 2 に示した症例 $2 ， 3 ， 15 ， 1604$ 例 が現在生存しており, うち 3 例は術後 8 年 4 力 月, 8 年 1 力月と 2 年10力月で癌の再発は認め ず健在である。このうち症例 3 は肺多発癌で あり, 左上葉切除後 1 年半後に反対側右上葉肺 $\left(\mathrm{B}^{2} \mathrm{a}\right)$ に扁平上皮癌が発生し，乙の部に $50 \mathrm{~Gy}$
表 4 高歯者肺癌切除16例

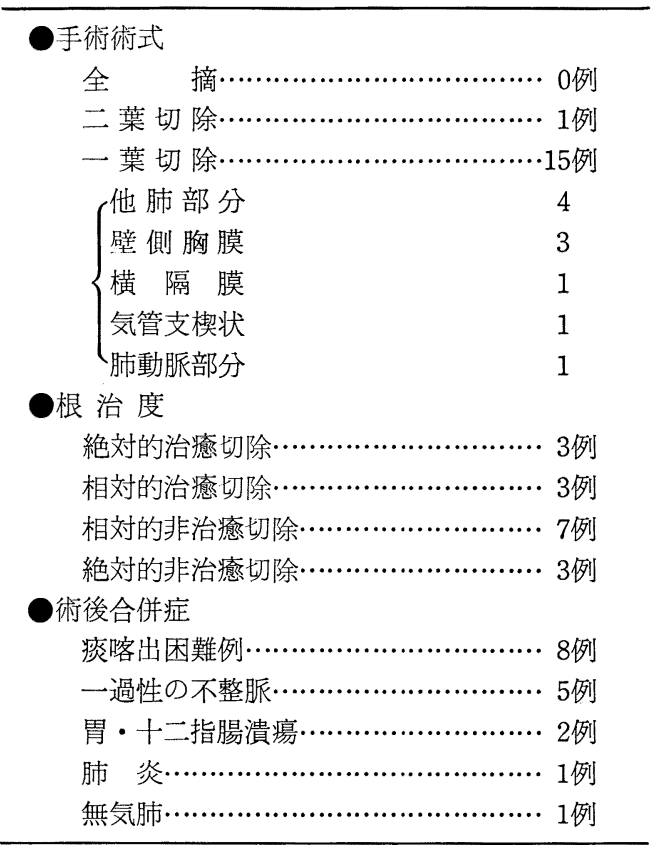

の放射線治療をお乙ない，術後 8 年11力月の現 在再発なく健在である.

死亡例 12 例のうち症例 $6,8,12$ は 3 年以上 の生存例で，いずれも在宅死亡例であるが，明 らかな癌死は 1 例のみであった。

その他の死亡例 9 例では 2 年〜 4 力月の癌死 が 6 例，他病死は 3 例であるが，乙れらの 1 例 が術後27日目に 2 例がそれぞれ 3 力月，5 力月 に肺炎にて死亡した.

(80才以上高齿者肺癌切除例)

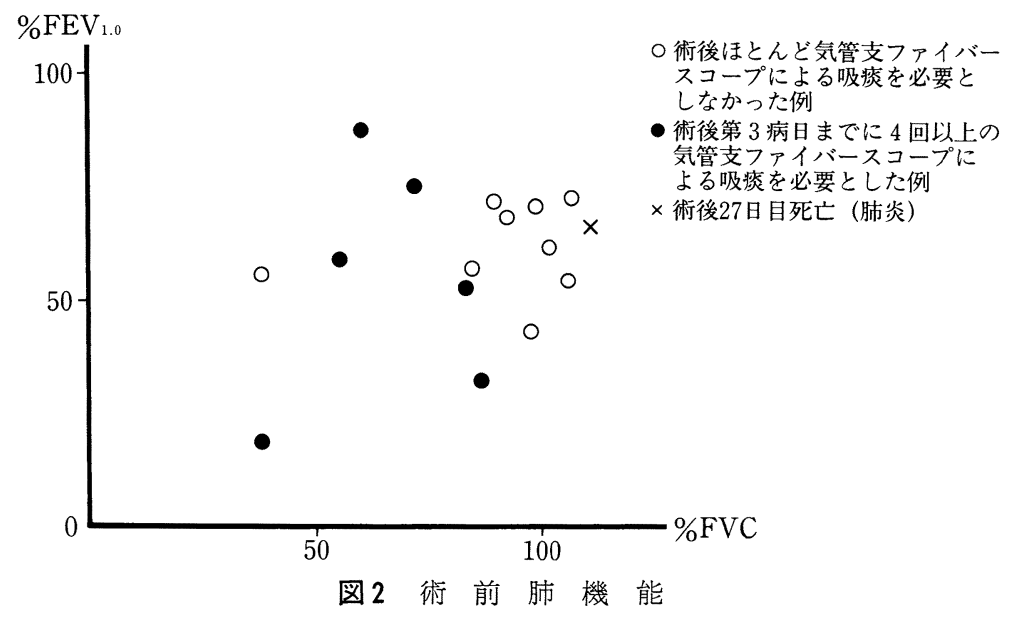




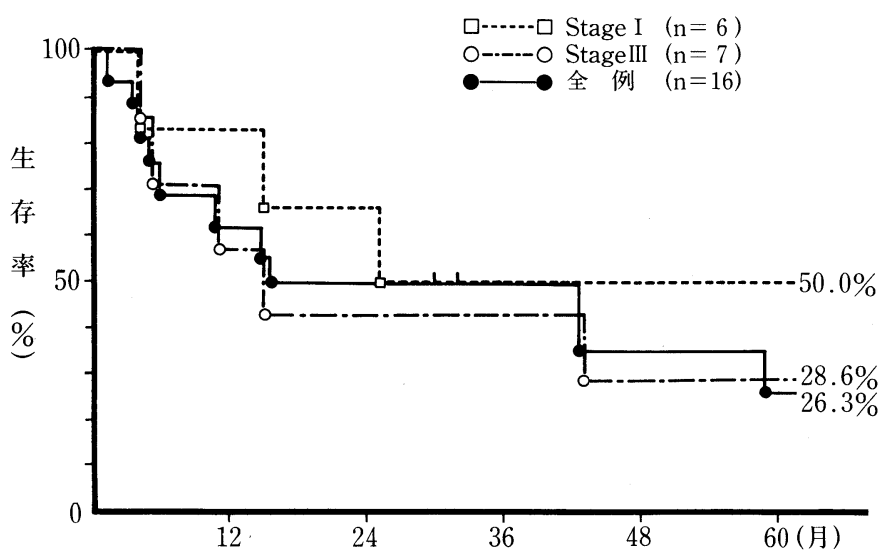

図 380 才以上高齢者肺癌切除例の生存曲線

\section{考 察}

近年，本邦において屯肺癌は年々増加の傾向 にあるが，平均寿命の延長とともにより高齢者 肺癌の占める割合が増加している．それにとも ない高齢者に対する手術適応も拡大され，高齢 者の手術療法に関した多くの報告 ${ }^{2}{ }^{2}$ 㱙みられ， 年龄による手術適応についても時代とともに年 々その限界が上昇している。現在では80才以上 の肺癌切除例の報告6 11) 屯散見され，その中に は長期生存例むみられるようになってきた。す なわち，80才以上の高榆者といえどあ手術によ って治癒あるいは延命効果が期待される肺癌症 例に対しては，従来から言われているように暦 年齢とは別に生理学的な年齢を十分に考慮して 手術適応を決定する必要があり，適切な術前心 肺機能の評価とともに，術中および術後の十分 な管理によって手術療法が可能であり，よりよ い予後が得られると考える。しかし，高齢者で は加齢に伴う臓器の退行変性や既往の疾患によ る機能低下のため，若年者に比べて併発症の頻 度が高くなり2)，また多臓器の重複合併症も加

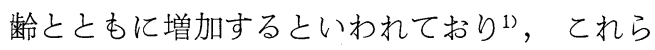
が高齢者肺癌術後の心肺合併症増加とそれに続 く死亡率の増加となっている4 ${ }^{4}$.

手術術式については現在肺癌例において肺葉 切除あるいは肺摘除に縦隔リンパ節郭清術を行 うことが定型的とされており，我々も高齢者と
いえども手術としては肺葉切除を原則としてい る.ここで報告した16例も全例が肺葉切除（1 例は 2 葉切除）である. しかし，肺全摘術は乙 れらの高㱓者ではその予備力も少なく，侵襲が より大きいため，合併症も多くなり，術後の quality of life を考えた場合にもその demerit が大きく，できるだけ避ける方針12)で， sleeve lobectomy や近隣肺葉の部分切除等で工夫 ${ }^{5)}$ し ている．同様に呼吸機能低下をできるだけ少な くするために，呼吸筋を切断しないなどその開 胸方法の工夫 ${ }^{13)}$ 屯必要と考えている。 また，低 肺機能例や重複癌例で機能温存をはかるべき症 例では limited operation む考慮すべきと考え る ${ }^{14)}$ が，今回報告した16例中 Stage I の 7 例 では全例 $3 \mathrm{~cm}$ 以上の T2 例であり，不十分な 切除に終わる可能性が高いと思われる。しかし， 肺多発癌の増加 ${ }^{15)} や よ り$ 高齢者に対する外科治 療の問題として, その適応は今後重要な課題と なると考える．また発見動機として 6 例が自覚 症状発見であったことは，80才以上の高齢者に おいても早期発見の必要性を痛感する.

縦隔リンパ節郭清については，我々も前期の 8 例（症例 1 ～8）では，その侵襲を考え肺葉 切除に R0〜 R1 のリンパ節郭清術を加えるの みとしていたが，後期の 8 例では全身状態さえ よければ根治手術をめざすとの考えより縦隔り ンパ節郭清を行っている。術前診断では Noと 考えたが，術後 7 例中 2 例が N2 であった，縦 
隔リンパ節郭清のための明らかな合併症の増加 はみられなかったが，縱隔リンパ節郭清におい て問題となるのは反回神経損傷 5 ) 之咳嗽反射の 減弱卓である.

現在は迷走神経支を温存したリンパ節郭清を 行なっているが，Cusa 等の使用も1つの方法 と考えている. 高齢者の術後合併症の頻度では まず頻脈, 不整脈等の循環器系の合併症が多く, 次いで呼吸器系, 消化器系, 精神的な合併症で あるが，呼吸器系合併症の発生は直接死因につ ながる可能性があり ${ }^{2,4)}$, 術後の気道内分泌物の 増加や喀出力の低下がおおいに関与する，高齢 者はドレーン挿入部や創部の痛みにより動きや 咳を自制し，疼痛の訴えとしては少ないてとも あるが，乙れが術後の合併症を併発する原因と なるため, 術後の疼痛対策と痰のコントロール は非常に大切である，我々は術前あるいは術直 後に硬膜外チューブを挿入し，乙れより 1 日 2 回の鎮痛剂投与と術後 $1 \sim 3$ 日の早朝の気管支 ファイバースコープによる痰の確認あるいは吸 痰を行っている．また高齢者では特に術前より の禁煙，咳嗽や深呼吸の指導または術後の早期 離床が重要であることは言うまでもない。

高齢者肺癌手術例の手術死亡率は外国文献で は，以前は Kirsh ら ${ }^{17)}(1976)$ 14\%, Harviel ら ${ }^{18)}(1978) 18 \%$ と高率であったが，最近では Breyer ら ${ }^{14)}$ (1981) の $4 \% や$ Ginsberg ら ${ }^{19}$ （1983）による Lung Cancer Study Group の 集計報告では70才以上で7. $1 \%$ ，80才以上で屯 8. 1\%あるいは Martini (1986) ${ }^{12)}$ の $2 \%$ とった 良好な報告がみられる。本邦においても70才以 上で $6.2 \%$ 10. $4 \% \%^{4,5,16)} 80$ 才以上でも大畑ら ${ }^{6)}$ の集計で $6 \%$ と報告されており，80才未満の肺 癌切除例のそれに劣らない数値となってきてい る.

また予後については70才以上の高齢者の 5 年

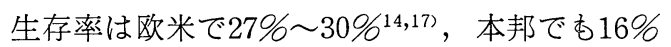
〜30.1\%の報告 ${ }^{4,5)}$ がみられるが，今回我々の 報告した 80 才以上 16 例全体の 5 年生存率 $26.3 \%$ はこれらに劣らない.

またてのうち Stage I（術死 1 例を除く）の 5 年生存率は $50 \%$, Stage III 28.6\%であり，乙
れは水上ら ${ }^{20)}$ の高齢者肺癌の対症療法のみの臨 床病期 I 期 26 例の 5 年生存率 $19 \%$ より良好であ る。

\section{結 語}

当院に怙ける16例の 80 才以上肺癌切除例につ いて報告した．高齢者肺癌の増加に伴い80才以 上の肺癌手術例も今後ますます增加するあの之 思われる，そのさい高齢者では平均余命や手術 侵襲の大きさを考えると手術適応を厳密にすべ き事はもちろんのことであるが，肺癌に対し根 治を目的とした治療法で手術以上の手段のない 現在，80才以上であっても 1 例 1 例詳細な検討 により積極的に手術を行うべきである. 術前併 発症の多い高齢者では術後合併症む多く, 術中 術後の厳重な管理と共に術後の社会あるいは家 庭生活への復帰を考慮した手術適応が重要であ る.

本論文の要旨は第39回日本胸部外科学会総会に おいて報告した。

\section{文献}

1）沢村献児, 長岡 豊, 近森淳二, 等: 胸部外科に おける老人外科の問題点とその対策，医療， 32 : 1452-1461, 1978.

2) 土井 修, 鍋島秀雄, 岡本信洋, 等 : 肺癌, 臨床 胸部外科, $1: 505-515,1981$.

3）佐藤日出夫, 岩 喬, 渡辺洋宇, 等: 高令者肺 癌手術症例の解析, 胸部外科, $34: 454-458,1981$.

4）富田正雄, 綾部公懿, 川原克信, 等: 高齢者肺癌 の外科治療, 臨床胸部外科, $4: 337-341,1984$.

5）土屋了介, 宮沢直人, 成毛韶夫, 等 : 高令者肺癌 の治療成績. 胸部外科, $34: 416-420,1981$.

6）大畑正昭：80歳以上超高齢者肺腫瘍の治療一之< 飞外科的治療を中心に一, 日胸, $42: 275-282$, 1983.

7）荒井他嘉司, 平田正信, 木村荘一, 等 : 84才の肺 癌症例飞㧍ける肺葉切除術の経験. 胸部外科, $34: 459-463,1981$.

8）坂元隆一，鈴木一也，長島康之，等：80歳以上超 高齢者肺癌の 2 切除例. 胸部外科, $38: 634-638$, 1985.

9）服部良二, 竹内義広, 木村 誠, 等: 80才以上の 高令者肺癌に対する外科治療経験。肺癌, 25 ： 1037-1041， 1985.

10）筒井正好, 岩崎昭憲, 草野卓雄, 等: 80歳以上超 高齢者肺癌患者に対する外科治療. 日胸, $46: 53$ 2-539, 1987. 
11）寺田泰二, 松延政一, 根本 正, 等 : 高齢者 (80 歳以上) の肺癌手術 6 例の検討. 胸部外科, 41 : 291-294, 1988.

12) Martini N: Lung cancer in the elderly. Front. Radiat. Ther. Onc., 20: 125-132, 1986.

13) Bethencourt DM, Holmes EC: Muscle-sparing posterolateral thoracotomy. Ann Thorac Surg, 45: 337-339, 1988.

14) Breyer RH, Zippe C, Pharr WF, et al: Thoracotomy in patients over age seventy years. Tenyear experience. J Thorac Cardiovasc Surg, 81: 187-193, 1981.

15）西山祥行，児玉哲郎，黒木基夫，等 : 原発性肺多 発癌例の検討，日胸，47:564-572，1988.

16）広野達彦，坂下 熏，山崎芳彦，等 : 高令者肺癌 に対する肺切除術の問題点一とくに肺合併症と縦
隔郭清について一胸部外科, $34: 441-443 ， 1981$.

17) Kirsh MM, Rotman H, Bove E, et al: Major pulmonary resection for bronchogenic carcinoma in the elderly. Ann Thorac Surg, 22: 369-373, 1976.

18) Harviel JD, McNamara JJ, Straehley CJ: Surgical treatment of lung cancer in patients over the age of 70 years. J Thorac Cardiovasc Surg, 75: 802-805, 1978.

19) Ginsberg RJ, Hill LD, Eagan RT, et al: Modern thirty-day operative mortality for surgical resections in lung cancer. J Thorac Cardiovasc Surg, 86: 654-658, 1983.

20）水上陽真, 木村雄二, 福島保喜 : 老年者の腫瘍, 肺癌, Geriat Med, 18: 1323-1333, 1980.

\title{
Surgical Treatment of Lung Cancer in 16 patients over the age of 80 years.
}

\author{
Hiroyuki Nishiyama, Motoo Kuroki, Mitsuyo Nishimura, Hideto Kaneyasu, \\ Kenro Takahashi, and Tomoji Matsuyama
}

Department of Surgery, Matsudo National Hospital, Chiba

Sixteen patients with lung cancer over 80 years of age $(4 \%$ of the total number of those operated on for lung cancer) were treated surgically during the past 7 years at our hospital. Thirteen patients were male and three were female. Seven patients had stage I disease, seven had stage III disease and two had stage IV disease. The histology of the tumor was adenocarcinoma in seven, squamous cell carcinoma in seven, large cell carcinoma in one, and small cell carcinoma in one. The diagnosis of lung cancer was based on symptoms in nine patients, during treatment for other diseases in six, and by mass screening in only one patient.

Lobectomy was performed in 15 patients and bilobectomy in one. Mediastinal dissection was not performed in the first eight patients but was performed in the later group of eight.

The 5 -year survival rate was $26.3 \%$. One patient died within 30 days after operation (operative mortality rate $9 \%$ ).

We concluded that some patients over 80 years of age are candidates for surgery after careful evaluation of the stage of disease, pulmonary function and the curativity of the procedure and should receive intensive care after surgery. 